\title{
THE EFFECT OF FINANCIAL LEVERAGE ON PROFITABILITY: AN EMPIRICAL ANALYSIS OF RECAPITALIZED BANKS IN GHANA
}

\author{
Dr. Alhassan Bunyaminu \\ Lecturer \\ Faculty of Accounting and Finance \\ University of Professional Studies, Accra, Ghana \\ E-mail: alhassan.bunyaminu@upsamail.edu.gh \\ Mr. Ibrahim Nandom Yakubu \\ PhD Candidate \\ Department of Banking and Finance \\ Ankara Yildirim Beyazit University, Turkey \\ E-mail: kassiibrahim@gmail.com \\ Dr. Shani Bashiru \\ Dean of Business School \\ Accra Technical University, Accra, Ghana \\ E-mail: shanibash@yahoo.co.uk
}

\begin{abstract}
In this study, we examine the impact of financial leverage on profitability of recapitalized banks in Ghana over the period 2008-2017. Based on the random effects and fixed effects estimation strategies, our findings reveal that leverage exerts a significant negative effect on banks' profits regardless of the proxy of profitability. This provides empirical support for the pecking order theory. The results also establish that bank size positively and significantly enhances profitability. In light of our findings, we conclude that financial leverage is detrimental to banks' profit growth in Ghana.
\end{abstract}

Keywords: Leverage, Bank Size, Profitability, Random Effects, Fixed Effects, Ghana.

JEL Classification Codes: G21, G30.

\section{INTRODUCTION}

Globally, the banking sector has undergone significant transformations for the past decades with banks activities and performance being influenced by both internal and external factors. Banks generally contribute to economic growth through their intermediation functions and the financing of economic activities (Ünvan \& Yakubu, 2020). A central aspect of banks which aids in smoothening economic activities is the level of profitability. The significance of banks' profit growth is manifested at both the micro (bank characteristics) and macro levels. Profitability at the bank level is viewed as a prerequisite for competitiveness and ensuring a sustainable banking institution. Owing to banking sector competition in recent years, profits are essential to sustaining competition in the industry and necessary for continual operations (Bobakova, 2003). In the 
macroeconomic setting, negative shocks immensely affect bank activities, and a profitable banking sector can absorb these shocks. Thus, contributing to a stable financial system.

Given the significance of bank profitability, the factors affecting profit growth have gained research attention and have interested bank management and regulators. The existing literature has highlighted how bank-specific factors, industry-level indicators, and macroeconomic environment affect banks profit level in both developed and developing economies (Sufian \& Habibullah, 2009; Davydenko, 2010; Dietrich \& Wanzenried, 2011; Sufian, 2012; Roman \& Danuletiu, 2013; Dietrich \& Wanzenried, 2014; Echekoba et al., 2014; Messai et al., 2015; Menicucci \& Paolucci, 2016; Yakubu, 2016; Islam \& Rana, 2017; Oyerinde, 2017; Salike \& Ao, 2018; Akber, 2019; Batten \& Vo, 2019; Yakubu, 2019; Bezawada, 2020; Hasan et al., 2020; Hoque et al., 2020).

In the profitability determinants literature, capital structure (financial leverage) is among the variables accorded significance and has been extensively examined. Nonetheless, a consensus on how it influences profitability is yet to be established given the varying impact on profit across sectors. Besides, studies on how financial leverage drive profitability dwell more on non-financial firms (see Azhagaiah \& Gavoury, 2011; Anthony, 2013; Mwangi et al., 2014; Rouf, 2015; Yapa, 2015; Habib et al., 2016; Akani \& Ifechi, 2017; Akomeah et al., 2018; Rahman et al., 2019; Musah \& Kong, 2019) with little focus on financial firms. Particularly in Ghana, scanty evidence is documented in the case of banks, hence presenting an avenue for more research efforts. The empirical works of Gatsi and Akoto (2010), Awunyo-Vitor and Badu (2012), Thomas et al. (2012), and Yakubu et al. (2017) are among the few studies on how capital structure (leverage) affects banks profitability in Ghana. Aside from the time limitations of these studies, the use of a single proxy of profitability may not produce robust findings.

Consequently, this study seeks to add to the limited attempts by critically investigating the influence of leverage on profitability of Ghanaian banks. Our paper significantly makes two contributions to the extant literature. First, in addition to return on assets which is widely studied, we introduce net interest margin as an additional profitability proxy to ensure the robustness of our results. Second, unlike other studies, we employ recent data of the newly recapitalized banks in Ghana.

The rest of our paper is structured as follows: In Section 2, we elaborate on the literature pertaining to our study. Section 3 explains our data and approach. The empirical analysis is outlined in Section 4, and we conclude in Section 5.

\section{LITERATURE REVIEW}

Theoretically, how capital structure influences firm value has received much debate in the literature. The central argument relates to whether firms maintain an ideal level of capital structure or whether using more debt matters for firm value. The formative work of Modigliani and Miller (1958) inspired the research on capital structure and presented the framework for the emergence of other theories in capital structure studies. Modigliani and Miller presumed that capital structure does not in any way contribute to the value of firms. Hence, assuming irrelevancy of capital structure. This claim of the M\&M model is underpinned with some assumptions considered restrictive and unrealistic. The theory assumed a perfect capital market, firms operating with zero taxes, and the absence of transaction costs. Following the criticisms of the irrelevancy assumption, Modigliani and Miller in 1963 revised their previous claim to reflect that debt matters for firm value. They incorporated the benefit of tax-shields in the use of debt. M\&M (1963) opined that firms can maximize value by employing a higher level of leverage. 
In advancement to the M\&M (1963) theory, is the trade-off hypothesis. It assumes that firms can ensure value maximization by maintaining a debt structure that brings tax benefits and reduces bankruptcy risk (Myers, 1984). Hence, the trade-off theory advocates for an optimum level of capital structure for firms. On the contrary, the proposition by Myers and Majluf (1984) referred to as the pecking order theory hypothesizes a preferential order which firms must adhere to in their capital structure decisions. First, internal financing is prioritized, and firms will employ debt when external funding is required. Issuing equity is the last financing strategy by firms under the pecking order hypothesis.

Turning to the empirical works, the influence of leverage on firms' profitability is mixed as findings vary across sectors. In this section, we review the empirical studies for both nonfinancial firms and financial firms.

In the case of non-financial firms, Shubita and Alsawalhah (2012) for instance, assessed how capital structure relates to profits of listed industrial firms in Jordan for the period 2004-2009. The authors found a significant and negative influence of leverage on firms' profit growth. Similarly, Anthony (2013) reported a negative and significant effect of leverage on the Ghanaian non-financial firms' profit level. Applying a panel approach, Mwangi et al. (2014) empirically studied the association between debt and firms' level of performance in Kenyan non-financial companies. The findings reported financial leverage to have a negative significant effect on firms' profits (proxied by return on asset and firms' return on equity). Yapa (2015) noted that long-term debt to total assets which measures firms' leverage negatively drives the profitability of SMEs operating in the UK. Habib et al. (2016) showed that regardless of the firms' capital structure indicator, the profitability of Pakistani non-financial firms is negatively and significantly predicted by their leverage level. Minnema and Anderson (2018) also documented an indirect correlation between leverage and Swedish firms' profitability level. Contrary to the negative findings, Kartikasari and Merianti (2016) evidenced that the impact of debt ratio on the profit growth of Indonesian manufacturing firms is positive and significant. A similar result is found by Rahman et al. (2019) in Bangladesh. Musah and Kong (2019) established that the ratios of debt-to-equity and firms' debt-to-total assets as capital structure indicators showed a direct though an insignificant impact on non-financial firms' profitability in Ghana.

For financial institutions, Goyal (2013) investigated how banks' debt level affect profitability in India for the period 2008-2014. Using different proxies of profitability, the author established a direct effect of short-term debt on profits. Birru (2016) indicated that banks' debt ratio positively and significantly influences banks' profitability. In establishing the nexus between capital structure and firm performance, Abbadi and Abu-Rub (2012) revealed a negative influence of leverage on banks' profitability and market value in Palestine. Chechet and Olayiwola (2014) also showed that a negative correlation exists between capital structure and Nigerian banks' profits growth. In Ghana, Thomas et al. (2012) noted that while banks long-term debt and firms' profitability have a positive significant relationship, the effect of short-term debt and total debt on banks' profit level is negative though significant. Anafo et al. (2015) reported that banks' profitability (measured by ROA) is positively driven by both banks' short-term and long-term debt levels. This is contrary to the results reported by Yakubu et al. (2017) who evidenced a negative influence of short-term and long-term debt on bank profits.

From the literature review, the effect of capital structure (leverage) on profit growth for both non-financial and financial firms is inconclusive. The measure of leverage and the different proxies of profitability may account for the inconsistent findings. This paper seeks to add to the unsettling debate and the limited research on the effect of leverage on banks' profits in Ghana. 


\section{Sample and Data}

\section{METHODOLOGY}

In this study, we employ data of eleven recapitalized banks covering the period 2008-2017. Seven of the sampled banks are foreign banks and four comprised of domestic banks. We gleaned the data from the banks' financial statements. Complete data availability informed the choice of our sample and the study period.

\section{Description of Variables}

We employ return on assets (ROA) and net interest margin (NIM) as dependent factors. ROA is defined as the ratio of banks' net income to total assets. NIM is computed as the ratio of banks' net interest to total assets.

Leverage (LEV) serves as the main independent variable which is defined as the ratio of total debts to total assets. We control for the effect of bank size (BSIZE) which has also been accorded significance in the literature as a profitability driver. The natural log of banks' total assets explains bank size.

\section{Model and Estimation Technique}

This study takes a panel approach and the model can be generally expressed as:

$$
\mathrm{Y}_{\mathrm{it}}=\alpha+\beta^{\prime} \mathrm{X}_{\mathrm{it}}+\varepsilon_{\mathrm{it}}
$$

where the dependent factor is $\mathrm{Y}$ and $\mathrm{X}$ signifies the explanatory factors. The cross-sectional dimension of our data is denoted by $i$ and the time dimension is indicated by $t . \alpha, \beta$, and $\varepsilon$ represent the constant, coefficients of the independent factors, and error term respectively.

To empirically analyze the effect of financial leverage alongside bank size on bank profitability, the model can be further expanded as:

$$
\begin{aligned}
& \mathrm{ROA}_{i t}=\alpha_{0}+\beta_{1} \mathrm{LEV}_{\text {it }}+\beta_{2} \mathrm{BSIZE}_{\mathrm{it}}+\varepsilon_{\mathrm{it}} \ldots \ldots \ldots \ldots \\
& \mathrm{NIM}_{\mathrm{it}}=\alpha_{0}+\beta_{1} \mathrm{LEV}_{\mathrm{it}}+\beta_{2} \mathrm{BSIZE}_{\mathrm{it}}+\varepsilon_{\mathrm{it}} \ldots \ldots \ldots \ldots
\end{aligned}
$$

We apply the fixed and random effects techniques as our estimation strategies. These techniques consider the group and time effects of panel data which is ignored in the ordinary least squares (OLS) estimation. To choose an appropriate technique, we perform the Hausman (1978) test. A probability value (p-value) of less than 5\% statistical significance suggests the preference of the fixed effects technique, and thus the random effects assumptions are rejected. A p-value greater than $5 \%$ means rejection of the fixed effects model, and the OLS or the random effects model is chosen based on the Breusch-Pagan test results.

\section{Descriptive Statistics and Correlation Analysis}

\section{EMPIRICAL RESULTS}

Table 1 displays the descriptive statistics of all the variables for our sample banks. It illustrates the average, standard deviation, minimum, and maximum values of the variables estimated from the banks' financial statements. Return on assets (ROA) shows an average of $4.3 \%$ which has a maximum of $9.3 \%$ and a minimum of $-4.7 \%$. The mean of banks' net interest margin (NIM) is $8.1 \%$. The low standard deviation values of ROA and NIM relative to their averages depict less volatility in the banks' profits. Leverage (LEV) reveals a mean of 0.853 , suggesting that the banks 
are highly leveraged, and employ about $85.3 \%$ debt to finance banks' total assets. Bank size (BSIZE) is averaged at 14.28.

The correlation analysis is also presented in Table 1 . We argue that our variables are free from multicollinearity issues given their weak association and high tolerance values.

Table 1. Descriptive statistics and multicollinearity analysis

\begin{tabular}{|l|r|r|r|r|}
\hline & ROA [1] & NIM [2] & LEV [3] & BSIZE [4] \\
\hline Mean & 0.043 & 0.081 & 0.853 & 14.283 \\
\hline Std Dev. & 0.028 & 0.024 & 0.043 & 0.885 \\
\hline Maximum & 0.093 & 0.160 & 0.956 & 16.080 \\
\hline Minimum & -0.047 & 0.030 & 0.690 & 12.070 \\
\hline Observations & 110 & 110 & 110 & 110 \\
\hline$[1]$ & 1.000 & & & \\
\hline$[2]$ & 0.415 & 1.000 & & \\
\hline$[3]$ & -0.300 & -0.364 & 1.000 & \\
\hline$[4]$ & 0.297 & 0.493 & -0.018 & 1.000 \\
\hline VIF & & & 1.00 & 1.00 \\
\hline Tolerance & & & 0.999 & 0.999 \\
\hline
\end{tabular}

\section{Regression Results}

The regression results on leverage and bank profitability relationship are contained in Table 2. From the estimations in Model 1, the fixed effects (FE) technique is rejected as the probability value of the Hausman test exceeds 5\% significance level. The significance of the Breusch-pagan test at 5\% level lends support to the random effects technique. Hence, the interpretations of our findings in Model 1 is based on the estimation of the random effects (RE). The 5\% significance of the Hausman test in Model 2 suggests the use of the fixed effects estimation. In Models 1 and 2, the $\mathrm{R}^{2}$ values respectively illustrate that the explanatory factors predict only $14.9 \%$ and $39.3 \%$ variations in banks' profitability. The Wald test of the random effects estimation in Model 1 and the F-statistics of the fixed effects estimation in Model 2 prove that our estimated models are valid.

Table 2. Regression results

\begin{tabular}{|l|c|c|c|c|}
\hline & \multicolumn{2}{|c|}{ Model 1 (ROA) } & \multicolumn{2}{c|}{ Model 2 (NIM) } \\
\hline Variables & FE & RE & FE & RE \\
\hline LEV & $-0.183^{* * *}$ & $-0.181^{* * *}$ & $-0.201^{* * *}$ & $-0.197^{* * *}$ \\
\hline BSIZE & $(0.058)$ & $(0.055)$ & $(0.039)$ & $(0.038)$ \\
\hline & $0.005^{*}$ & $0.006^{* *}$ & $0.009^{* * *}$ & $0.010^{* * *}$ \\
\hline $\mathrm{C}$ & $(0.003)$ & $(0.003)$ & $(0.002)$ & $(0.002)$ \\
\hline & $0.126^{*}$ & 0.105 & $0.123^{* *}$ & $0.107^{* *}$ \\
\hline Diagnostics & $(0.074)$ & $(0.068)$ & $(0.050)$ & $(0.048)$ \\
\hline $\mathrm{R}^{2}$ & & & & 0.392 \\
\hline Hausman test $\chi^{2}$ & 0.151 & 0.149 & 0.393 & \\
\hline$\left[\right.$ Prob.> $\left.\lambda^{2}\right]$ & 0.56 & & 6.55 & \\
\hline Breusch-Pagan test $\lambda^{2}$ & {$[0.059]$} & & & \\
\hline
\end{tabular}




\begin{tabular}{|l|c|c|c|c|}
\hline$\left[\right.$ Prob. $\left.>\chi^{2}\right]$ & & {$[0.000]$} & & \\
\hline F-statistic & 8.61 & & 31.37 & \\
\hline Prob.(F-statistic) & {$[0.000]$} & & {$[0.000]$} & \\
\hline Wald $\chi^{2}$ & & 19.62 & & 66.71 \\
\hline$\left[\right.$ Prob. $\left.>\lambda^{2}\right]$ & & {$[0.000]$} & & {$[0.000]$} \\
\hline Observations & 110 & 110 & 110 & 110 \\
\hline No. of Banks & 11 & 11 & 11 & 11 \\
\hline
\end{tabular}

Notes: $* * *$ and $* * *$ represent $10 \%, 5 \%$ and $1 \%$ statistical significance respectively. Values in ( ) and [ ] are standard errors and $p$-values respectively.

From the estimation in Model 1, leverage significantly and negatively affect banks' profitability (measured by ROA) at 1\% significance level. A similar result is reported in Model 2 when net interest margin (NIM) proxies banks' profitability. The finding generally portrays that as Ghanaian banks demand more on debt as a financing method, their profit level reduces. A plausible implication is that banks may tend to spend more of their profits on servicing the interest on debt and thus retaining less funds to carry out their activities. As established in the descriptive statistics, the sampled banks are highly leveraged, and more of their earnings are likely to be directed to interest payments. Our finding supports prior studies (Abbadi \& Abu-Rub, 2012; Chechet \& Olayiwola, 2014; Yakubu et al., 2017).

In both models, bank size positively and significantly affects profitability. This means that as banks expand, their profitability level is enhanced. This is consistent with the rapid branch expansion strategies of commercial banks in Ghana. The result also syncs with the argument that diversification strategies are easily undertaken by larger banks which help in boosting profits (Yakubu, 2019).

\section{CONCLUSION AND RECOMMENDATIONS}

In this study, we empirically examined the effect of leverage on banks' profit growth in Ghana while controlling for bank size. We employed the panel random effects and fixed effects techniques on bank-level data of eleven recently recapitalized banks in Ghana. Unlike prior studies, this paper considered two key measures of profitability to ensure consistent findings. From the analysis, we found that leverage negatively and significantly affects banks' profitability regardless of our indicator of profitability. This lends support for the pecking order theory. Bank size exerted a positive significant influence on both profitability measures. In essence, we conclude that while bank size is vital for banks' profits, leverage impedes the profitability of Ghanaian banks. Based on these findings, we recommend that banks should resort to internal financing to fund their projects and operations given that leverage inhibits their profitability. Banks can also ensure profit growth by improving their asset base via branch expansion strategies.

\section{REFERENCES}

Abbadi, S. M., \& Abu-Rub, N. (2012). The effect of capital structure on the performance of Palestinian financial institutions. British Journal of Economics, Finance and Management Sciences, 3(2), 92-101.

Akani, H. W., \& Ifechi, K. N. J. (2017). Effects of capital structure and board structure on corporate performance of selected firms in Nigeria. Indian Journal of Finance and Banking, 1(2), 1-16. 
Akber, S. M. (2019). Influential Factors Responsible for Profitability: A Technical Study on Commercial Banks in Bangladesh. International Journal of Accounting \& Finance Review, 4(2), 22-28.

Akomeah, E., Bentil, P., \& Musah, A. (2018). The Impact of Capital Structure Decisions on Firm Performance: The Case of Listed Non-Financial Institutions in Ghana. International Journal of Academic Research in Accounting, Finance and Management Sciences, 8(4), $1-15$.

Anafo, S. A., Amponteng, E., \& Yin, L. (2015). The impact of capital structure on profitability of banks listed on the Ghana Stock Exchange. Research Journal of Finance and accounting, 6(16), 26-34.

Anthony, H. (2013). Capital Structure and Profitability of Selected Listed Non-financial Firms in Ghana. International Journal of Business and Social Sciences, (2), 1-30.

Awunyo-Vitor, D., \& Badu, J. (2012). Capital Structure and Performance of Listed Banks in Ghana. Global Journal of Human Social Sciences, 12(5), 57-62.

Azhagaiah, R., \& Gavoury, C. (2011). The Impact of Capital Structure on Profitability with Special Reference to IT Industry in India. Managing Global Transitions: International Research Journal, 9(4), 371-392.

Batten, J., \& Vo, X. V. (2019). Determinants of bank profitability-Evidence from Vietnam. Emerging Markets Finance and Trade, 55(6), 1417-1428.

Bezawada, B. (2020). Corporate Governance Practices and Bank Performance: Evidence from Indian Banks. Indian Journal of Finance and Banking, 4(1), 33-41.

Birru, M. W. (2016). The impact of capital structure on financial performance of commercial banks in Ethiopia. Global Journal of Management and Business Research. 16(8), 44-52.

Bobakova, V. (2003). Possibilities of the increasing of the profitability of a commercial bank. Biatec, 11(4), 26-29.

Chechet, I. L., \& Olayiwola, A. B. (2014). Capital structure and profitability of Nigerian quoted firms: The agency cost theory perspective. American International Journal of Social Science, 3(1), 139-158.

Davydenko, A. (2010). Determinants of bank profitability in Ukraine. Undergraduate Economic Review, 7(1), 2.

Dietrich, A., \& Wanzenried, G. (2011). Determinants of bank profitability before and during the crisis: Evidence from Switzerland. Journal of International Financial Markets, Institutions and Money, 21(3), 307-327. 
Dietrich, A., \& Wanzenried, G. (2014). The determinants of commercial banking profitability in low-, middle-, and high-income countries. The Quarterly Review of Economics and Finance, 54(3), 337-354.

Echekoba, F. N., Egbunike, C. F., \& Ezu, G. K. (2014). Determinants of bank profitability in Nigeria: Using Camel Rating Model (2001-2010). IOSR Journal of Business and Management, 16(9), 44-50.

Gatsi, J. G., \& Akoto, R. K. (2010). Capital structure and profitability in Ghanaian banks. Available at SSRN 1618952.

Goyal, A. M. (2013). Impact of capital structure on performance of listed public sector banks in India. International journal of business and management invention, 2(10), 35-43.

Habib, H., Khan, F., \& Wazir, M. (2016). Impact of debt on profitability of firms: Evidence from non-financial sector of Pakistan. City University Research Journal, 6(1), 70-80.

Hasan, M. S. A., Manurung, A. H., \& Usman, B. (2020). Determinants of Bank Profitability with Size as Moderating Variable. Journal of Applied Finance and Banking, 10(3), 153-166.

Hausman, J. A. (1978). Specification tests in econometrics. Econometrica: Journal of the econometric society, 46(6), 1251-1271.

Hoque, M. A., Ahmad, A., Chowdhury, M. M., \& Shahidullah, M. (2020). Impact of Monetary Policy on Bank's Profitability: A Study on Listed Commercial Banks in Bangladesh. International Journal of Accounting \& Finance Review, 5(2), 72-79.

Islam, M. A., \& Rana, R. H. (2017). Determinants of bank profitability for the selected private commercial banks in Bangladesh: A panel data analysis. Banks \& bank systems, 12(3),179-192.

Kartikasari, D., \& Merianti, M. (2016). The effect of leverage and firm size to profitability of public manufacturing companies in Indonesia. International Journal of Economics and Financial Issues, 6(2), 409-413.

Menicucci, E., \& Paolucci, G. (2016). The determinants of bank profitability: empirical evidence from European banking sector. Journal of financial reporting and Accounting, 14(1), 86115.

Messai, A. S., Gallali, M. I., \& Jouini, F. (2015). Determinants of bank profitability in Western European Countries evidence from system GMM estimates. International business research, 8(7), 30-42.

Minnema, J., \& Andersson, A. (2018). The relationship between leverage and profitability: A quantitative study of consulting firms in Sweden, Dissertation, Umeå University, Sweden. 
Modigliani, F., \& Miller, M. (1958). The cost of capital, corporation finance and the theory of finance. American Economic Review, 48(3), 291-297.

Modigliani, F., \& Miller, M. H. (1963). Corporate income taxes and the cost of capital: a correction. The American economic review, 433-443.

Musah, M., \& Kong, Y. (2019). The association between capital structure and the financial performance of non-financial firms listed on the Ghana Stock Exchange (GSE). International Journal of Research in Social Sciences, 9(5), 92-123.

Mwangi, L. W., Makau, M. S., \& Kosimbei, G. (2014). Relationship between capital structure and performance of non-financial companies listed in the Nairobi Securities Exchange, Kenya. Global Journal of Contemporary Research in Accounting, Auditing and Business Ethics, 1(2), 72-90.

Myers, S. C. (1984). The capital structure puzzle. The journal of finance, 39(3), 574-592.

Myers, S. C., \& Majluf, N. S. (1984). Corporate financing and investment decisions when firms have information that investors do not have. Journal of Financial Economics, 13(2), 187221.

Oyerinde, A. S. (2017). Bank Performance versus Recession Indicators: A Linear Cointegration Approach. Indian Journal of Finance and Banking, 1(1), 8-15.

Rahman, M. A., Sarker, M. S. I., \& Uddin, M. J. (2019). The Impact of Capital Structure on the Profitability of Publicly Traded Manufacturing Firms in Bangladesh. Applied Economics and Finance, 6(2), 1-5.

Roman, A., \& Danuletiu, A. E. (2013). An empirical analysis of the determinants of bank profitability in Romania. Annales Universitatis Apulensis: Series Oeconomica, 15(2), 580.

Rouf, D. (2015). Capital structure and firm performance of listed non-financial companies in Bangladesh. The International Journal of Applied Economics and Finance, 9(1), 25-32.

Salike, N., \& Ao, B. (2018). Determinants of bank profitability: role of poor asset quality in Asia. China Finance Review International, 8(2), 216-231.

Shubita, M. F., \& Alsawalhah, J. M. (2012). The relationship between capital structure and profitability. International Journal of Business and Social Science, 3(16), 104-112.

Sufian, F. (2012). Determinants of bank profitability in developing economies: empirical evidence from the South Asian banking sectors. Contemporary South Asia, 20(3), 375-399. 
Sufian, F., \& Habibullah, M. S. (2009). Determinants of bank profitability in a developing economy: Empirical evidence from Bangladesh. Journal of business economics and management, 10(3), 207-217.

Thomas, K., Ababio, K. A., \& Zakari, A. (2012). Empirical Analysis of the Association between Capital Structure and Performance of Rural Banks in Ghana. Journal of Money, Investment and Banking, 124-130.

Ünvan, Y. A., \& Yakubu, I. N. (2020). Do bank-specific factors drive bank deposits in Ghana?. Journal of Computational and Applied Mathematics, 376, 112827.

Yakubu, I. N. (2016). Bank-Specific and Macroeconomic Determinants of Commercial Banks Profitability in Ghana. International Finance and Banking, 3(2), 89-99.

Yakubu, I. N. (2019). Does corruption grease or sand the wheels of bank profitability in ghana?. Cogent Economics \& Finance, 7(1), 1701909.

Yakubu, I. N., Alhassan, M. M., Mikhail, A. A., \& Alhassan, A. N. I. (2017). Commercial Banks Performance in Ghana: Does Capital Structure Matter?, International Journal of Accounting and Financial Reporting, 7(1), 333-342.

Yapa Abeywardhana, D. (2015). Capital structure and profitability: An empirical analysis of SMEs in the UK. Journal of Emerging Issues in Economics, Finance and Banking (JEIEFB), 4(2), 1661-1675.

\section{Copyrights}

Copyright for this article is retained by the author(s), with first publication rights granted to the journal. This is an open-access article distributed under the terms and conditions of the Creative Commons Attribution license (http://creativecommons.org/licenses/by/4.0) 